\title{
Az amerikai májmétely (Fascioloides magna) expanziója Délnyugat-Magyarországon - Előzetes közlemény
}

\section{HALÁSZ Tibor ${ }^{1,2}$, NAGY Gábor (iD) 2*, CSÁNYI Erika³, NÉMETH Sándor³, CSIVINCSIK Ágnes (iD) 2}

\author{
${ }^{1}$ SEFAG Zrt., 7400 Kaposvár, Bajcsy-Zsilinszky u. 21. \\ ${ }^{2}$ Szent István Egyetem Kaposvári Campus, 7400 Kaposvár, Guba S. u. 40. \\ 32Dél-Dunántúli Fauna Vadásztársaság, 7561 Nagybajom, Rózsalugas, 0423/1 hrsz.
}

\begin{abstract}
The expansion of giant liver fluke (Fascioloides magna) in southwestern Hungary Preliminary article

Author: Tibor Halász ${ }^{1,2}$, Gábor Nagy ${ }^{2 *}$, Erika Csányi ${ }^{3}$, Sándor Németh ${ }^{3}$, Ágnes Csivincsik ${ }^{2}$

Affiliation: ${ }^{1}$ SEFAG Forest Management and Wood Industry Share Co., HU-7400 Kaposvár, BajcsyZsilinszky str.. 21; ${ }^{2}$ Szent István University Kaposvár Campus, H-7400 Kaposvár, Guba S. str. 40; ${ }^{3}$ DélDunántúli Fauna Vadásztársaság, HU-7561 Nagybajom, Rózsalugas, 0423/1 hrsz.
\end{abstract}

The giant liver fluke Fascioloides magna has several continuously expanding natural endemics (northern Italy, the eastern region of Midle-Europe, mainly connected to the Danube (Austria, Slovakia, Hungary, Croatia, Serbia), and the connecting region of Germany, Czech Republic and Poland) in Europe. The giant liver fluke has an indirect life cycle, wherein mainly the red deer and fallow deer role as final hosts. To our present knowledge, in the European habitats, just three species (Galba truncatula, Radix peregra, Radix labiata) belonging to Lymnaeidae amphibian snails could be naturally infected and serve as the intermediate hosts of F. magna. The spread of the fluke is caused by the migration and transportation of infected definitive and intermediate hosts. This study is a part of a systematic regional monitoring programme with the aim of investigating different habitats within the southwestern part of Hungary to confirm the presence and spread of $F$. magna. In the study, the results of five shot red deer are presented. The livers went through with a thorough post-mortem examination. Isolated flukes were identified by morphological and molecular methods. In four cases, some worm specimens were detected; while in a male yearling, just marked pathological changes were observed in its liver. The morphology and the molecular diagnostic tests verified $F$. magna infection. The distances between the known northernmost presence in Inner-Somogy and the present shooting points were ranged from $21.0 \mathrm{~km}$ to $37.8 \mathrm{~km}$. These results showed a similar pattern as it was observed in other habitats around river Drava. Based on the distance data, the authors concluded that the worm is extending from South to North in the southwestern part of Hungary. Despite the habitat characterisation, viz lack of considerable constant water flows (rivers, creeks, ditches); it seems the high red deer density and the capable wet habitat patches, where the intermediate host could exist, may provide the continuous spread of F. magna.

Keywords: American liverwort, Fascioloides magna, red deer Cervus elaphus, Southern Transdanubia

*CORRESPONDING AUTHOR 


\section{BEVEZETÉS}

Az amerikai májmétely (Fascioloides magna) vadon élő és háziasított kérődzők, állategészségügyi szempontból fontos parazitája, mely kártételével jelentősen befolyásolhatja az állati termékek előállításának gazdaságosságát is. Európában a féreg végleges gazdája elsősorban a gímszarvas (Cervus elaphus) és a dámszarvas (Dama dama). Közvetett fejlődési ciklusában köztigazdaként pedig főként a törpe iszapcsiga (Galba truncatula) játszik kiemelkedő szerepet földrészünkön (Králová-Hromadová és mtsai., 2016).

A F. magna első észlelése Olaszországban történt a XIX. század végén. Egy vadaskertben találták meg vapitikben (Cervus canadensis) és fehérfarkú szarvasokban (Odocoileus virginianus), amelyeket az Amerikai Egyesült Államokból importáltak (Králová-Hromadová és mtsai., 2016). A XX. század második feléig Európa szerte csak sporadikus előfordulásai váltak ismertté. A jelenléte jellemzően olyan esetekhez volt köthető, melyek során ismeretlen állategészségügyi státuszú szarvasfélék importja történt Észak-Amerikából Uarnemo, 2009).

Az 1960-as évekre azonban szabad területi szarvas-állományokban élő stabil populációk alakultak ki Csehország területén, amely mára kiterjedt Lengyelország déli részeire is (Králová-Hromadová és mtsai., 2016). A harmadik góc, mely Ausztriát, Szlovákiát, Magyarországot, Horvátországot és Szerbiát köti össze, a Duna ártéri területeit foglalja magába (Majoros és Sztojkov, 1994; Rajský és mtsai., 1994; Giczi, 2008; Marinković és mtsai., 2013; Winkelmayer és Prosl, 2001; Marinculić és mtsai., 2002).

A parazita folyamatos terjedése napjainkban is tart. Vizsgálatok igazolták, hogy Csehországból a métely Németország irányába is terjed (Plötz és mtsai., 2015; Rehbein és mtsai., 2012), illetve az is bizonyítottá vált, hogy Magyarország déli határán, illetve attól északra, a Dél-Dunántúl belső területein is megjelent (Nagy és mtsai., 2018).

Mivel a féreg szarvas-populációkban kifejezett állategészségügyi jelentőséggel bír fontos az egyes régiók állományainak rendszeres monitorozása. A parazita jelenléte a végleges gazdák zsigereinek boncolása során könnyen igazolható. A férgek a májban és annak felszínén történő vándorlásuk során jellegzetes, szabad szemmel is jól látható elváltozásokat okoznak. A szervben megtelepedett és adulttá vált mételyek körül fehér falú, kötőszövetes tok alakul ki, amely pszeudociszta jól elkülönül a szerv parenchimájától (Swales, 1935; Králová-Hromadová és mtsai., 2016).

A lehetséges elterjedési területek szisztematikus monitorozása azért elengedhetetlen, mert a parazita megjelenése és továbbterjedése az érintett popu- 
lációk stabilitását gyengítheti, illetve az érintett területeken tartott haszonállatok termelésének gazdaságosságát is veszélyeztető tényezővé válhat (Campbell és Todd, 1954; Foreyt és Todd, 1972). Előzetes közleményünkben öt olyan gímszarvas amerikai májmétellyel való fertőzöttségét ismertetjük, amelyeket a parazita dél-dunántúli terjedését követő monitoring program keretében vizsgáltunk.

\section{ANYAG ÉS MÓDSZER}

\section{A vizsgálat helye és ideje}

Az állatokat Belső-Somogyban, egyéni vadászatok során ejtették el 2019. október 1-15. között (1. ábra). Az elejtés helyének koordinátáit mindegyik esetben rögzítettük. Ezek segítségével határoztuk meg a féreg-eddig ismert-legészakibb belső-somogyi előfordulása és az adott elejtések közötti távolságokat (Nagy és mtsai., 2018).

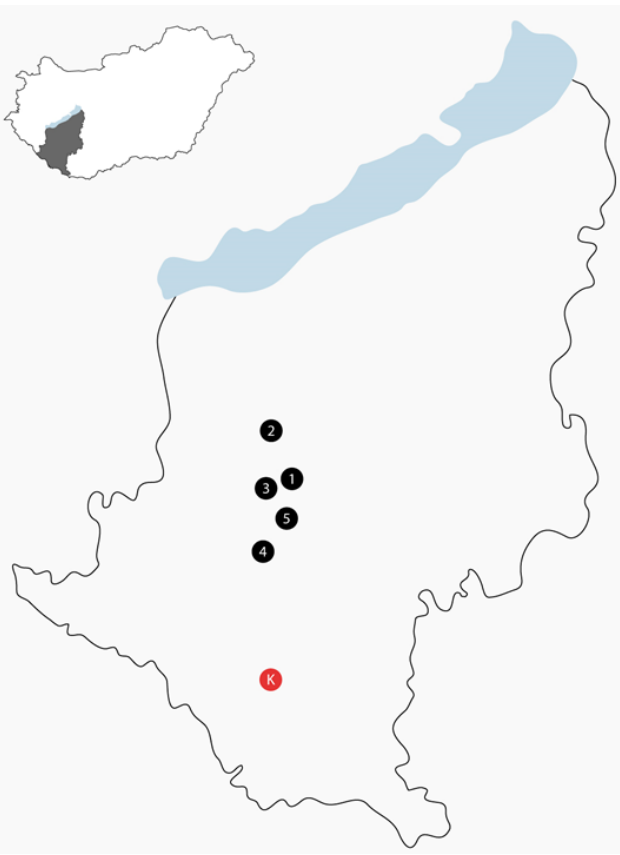

\section{1. ábra}

A gímszarvasok elejtési helyei (1-5) és a F. magna eddig ismert legészakibb előfordulása Belső-Somogyban (K). (Figure 1. Culling place of red deer (1-5) and the northernmost known presence of F. magna in InnerSomogy (K).) 
A mintagyűjtési terület Belső-Somogy északi peremén fekszik. Klímája szubmediterrán (700-800 mm éves csapadék, $10{ }^{\circ} \mathrm{C}$ körüli éves középhőmérséklet). Az 55-60\% közötti átlagos júliusi relatív páratartalomnak köszönhetően a terület a gyertyános-tölgyes erdészeti klímakategóriába tartozik. A területre jellemző egyik természetes fás társulás a gyetyános - kocsányos tölgyes (Querco robori - Carpinetum), amely azonban csak a területnek mintegy 1,5\%-át borítja (Führer, 2018). A terület legjellemzőbb erdős társulása (a terület 25,5 \%-án) az égeres, a teljes erdőborítottság pedig kb. 40\%. A vidék legjellemzőbb tájhasználati módja a mezőgazdálkodás (szántó- és gyepgazdálkodás), 60\% körüli aránnyal.

Az állandó felszíni vizek előfordulása Belső-Somogy e részén elhanyagolható. A területre inkább az időszakos vízfolyások jellemzőek, amelyek vízhozamát az aktuális csapadékmennyiség befolyásolja. A vadgazdálkodást a jelentős nagyvadállomány határozza meg; a terítékre hozott gímszarvasok éves mennyisége 1,1-1,3 állat/ $\mathrm{km}^{2}$. A terület további vadgazdálkodási jellegzetessége, hogy nagy és manapság is folyamatosan növekvő aranysakál-populáció él itt, amely részben betölti a csúcsragadozó, illetve a dögevő szerepét. Nagyobb testű ragadozófaj jelenléte a területen nem bizonyított.

\section{Parazitológiai és molekuláris diagnosztikai módszerek}

A laboratóriumi vizsgálatokat a szarvasok elejtését követően legfeljebb 24 órával végeztük. Az egész májat 1,0-1,5 cm-es szeletekre vágtuk, majd egy müanyag vödörbe helyeztük, ahol $37{ }^{\circ} \mathrm{C}$-os csapvízzel lemostuk. A szerv állományát a tárolóedényben kézzel szétnyomkodtuk. A beavatkozás után a nagyobb szövetdarabokat eltávolítottuk, a vödör aljában lévő üledéket pedig egy szita segítségével felfogtuk, amelyből az izolált férgeket összegyűjtöttük. A mételyek ivarérettségét a kavernákból gyüjtött folyadék mikroszkópos vizsgálatával bíráltuk el, melyekben petéket kerestünk.

A mételyek morfológiai azonosításához Králová-Hromadová és mtsai. (2016) munkáját használtuk (testalakulás, testhossz, szélesség). A molekuláris diagnosztikához, minden féreggel fertőzött egyedből egy-egy mételyt random kiválasztottunk. A féregből kb. 10-10 mg szövetet használtunk fel, amelyek lízisét $100 \mu$ 5\%-os Chelex 100 szuszpenzióban végeztük. Az azonosításhoz fajspecifikus primereket alkalmaztunk, amelyek segítségével a Fascioloides magna (forward: 5'-ACCAGTTATCGTTGTGTTG-3'; reverse: 5'-CCGTCTTTAAACAACAG-3') és a Fasciola hepatica (forward: 5'-CTTATGATTTCTGGGATAATT-3'; reverse: 5'-CCGTCGCTATATGAAAA-3') fajok egymástól egyértelműen 
megkülönböztethetőek (Houszka és mtsai., 2016). A PCR során kapott termékeket (Fascioloides magna 152 bp; Fasciola hepatica 112 bp) gélelektroforézissel (90 mV, 1 h) értékeltük 2\%-os agaróz gélen.

\section{EREDMÉNYEK}

A parazitológiai vizsgálatok során négy állatban, eltérő intenzitással, amerikai májmétely fertőzöttséget állapítottunk meg, míg egy fiatal bikában csak a féreg által okozott szöveti elváltozások jellegzetes nyomait találtuk (2. ábra). A májban petéket csak abban a tehénben találtunk, amelyből 29 férget sikerült izolálni.

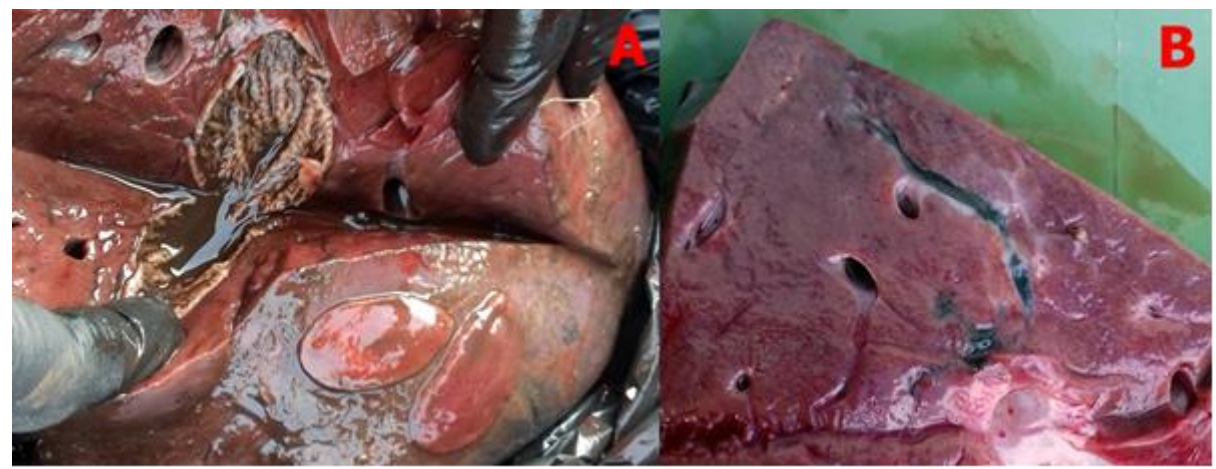

2. ábra

Adult F. magna férgek (A) és a métely szöveti kártételére utaló jellegzetes elváltozások (B) gímszarvas májában. (Figure 2. F. magna adults (A) and charcteristic pathological lesions caused by fluke migration (B) in red deer liver.)

Az izolált férgeken elvégzett morfológiai vizsgálat és a molekuláris diagnosztikai teszt is megerősítette a gímszarvasok $F$. magna fertőzöttségét ( 3 . ábra).

A távolságmérés során megállapítható volt, hogy a parazita 2018-ban megismert legészakibb belső-somogyi előfordulása és a jelenlegi előfordulási pontok közötti távolságok 21,0-37,8 km közé estek (1. táblázat).

\section{MEGBESZÉLÉS}

Európában, napjainkban a nagy amerikai májmétely előfordulásának legjelentősebb térsége a Duna vízgyűjtő területe, különösen annak ártéri szakaszai. A féreg jelenléte és terjedése több évtizede ismert, amely egyaránt érinti a FelsőDuna, és az Alsó-Duna ökorégiót (Majoros és Sztojkov, 1994; Rajský és mtsai., 1994; Marinković és mtsai., 2013; Winkelmayer és Prosl, 2001; Marinculić és 
mtsai., 2002). Az egyes ökoszisztémák közötti terjedésről azonban csak korlátozott ismeretekkel rendelkezünk (Florijančić és mtsai., 2010).

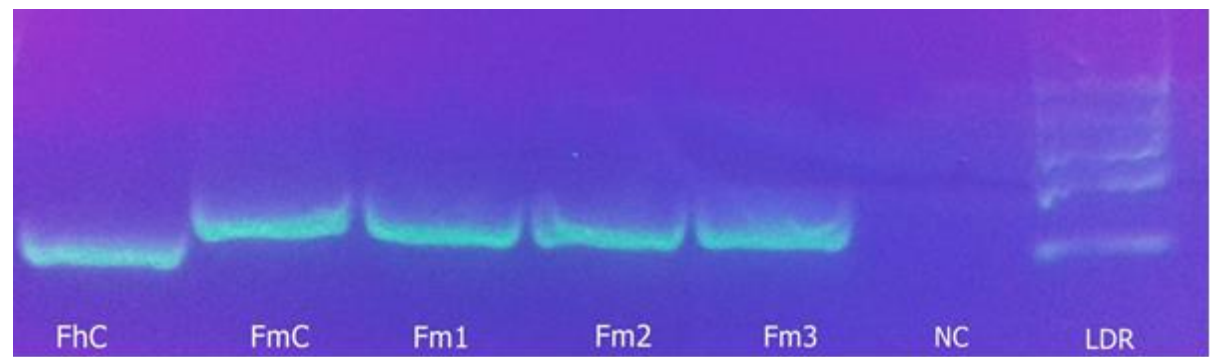

3. ábra

Néhány izolált féreg gélelektroforézisének eredménye. (FhC: $F$. hepatica kontroll, 112 bp; FmC: $F$. magna kontroll, 152 bp; Fm1, Fm2, Fm3: F. magna izolátum; NC: negatív kontroll; LDR: 100 bp létra). (Figure 3. Results by gelelectrophoresis of some isolated helminths. (FhC: F. hepatica control, $112 \mathrm{bp}$; FmC: F. magna controll, 152 bp; Fm1, Fm2, Fm3: iolated F. magna; NC: negative control; LDR: $100 \mathrm{bp}$ ladder).

\section{1. táblázat}

A leírt F. magna fertőzöttség parazitológiai és járványtani jellemzői

\begin{tabular}{|c|c|c|c|c|c|}
\hline $\begin{array}{c}\text { Elejtés } \\
\text { ideje }\end{array}$ & Ivar & $\begin{array}{c}\text { Életkor } \\
\text { (év) }\end{array}$ & Intenzitás & Koordináták & $\begin{array}{l}\text { Távolság a korábbi } \\
\text { előfordulástól }(\mathbf{k m})^{\S *}\end{array}$ \\
\hline 2019.10.01. & bika & 1,5 & 1 & $\begin{array}{l}46^{\circ} 24^{\prime} 46,40^{\prime \prime} \mathrm{E} \\
17^{\circ} 32^{\prime} 40,17^{\prime \prime} \mathrm{K}\end{array}$ & 31,26 \\
\hline 2019.10.06. & bika & 5 & 1 & $\begin{array}{l}46^{\circ} 28^{\prime} 28,16^{\prime \prime} E \\
17^{\circ} 29^{\prime} 41,08^{\prime \prime} \mathrm{K}\end{array}$ & 37,78 \\
\hline 2019.10.07. & tehén & 4 & 29 & $\begin{array}{l}46^{\circ} 24^{\prime} 21,22^{\prime \prime} E ́ \\
17^{\circ} 29^{\prime} 49,38^{\prime \prime} \mathrm{K}\end{array}$ & 30,16 \\
\hline 2019.10.07. & bika & 1,5 & $\begin{array}{l}\text { csak szöveti } \\
\text { elváltozás }\end{array}$ & $\begin{array}{l}46^{\circ} 19^{\prime} 23,77^{\prime \prime} \mathrm{E} \\
17^{\circ} 29^{\prime} 14,71^{\prime \prime} \mathrm{K}\end{array}$ & 20,96 \\
\hline 2019.10.15. & ünő & 1,5 & 10 & $\begin{array}{c}46^{\circ} 22^{\prime} 7,96^{\prime \prime} \text { É } \\
17^{\circ} 33^{\prime} 40,00^{\prime \prime} \mathrm{K}\end{array}$ & 26,69 \\
\hline
\end{tabular}

${ }^{\S}$ A távolságméréshez az előző vizsgálatunk alapján megállapított $46^{\circ}$ 8'5.25"É; 17²9'4.22"K referenciapontot használtuk. *Távolságmérés: Google Earth Pro szoftverrel (Google Ireland Limited, Gordon House, Barrow Street, Dublin 4, Ireland).

Table 1 Parasitological and epidemiological charcteristics of F. magna infection described in this study.

Egy 2017-2018. közötti időszakban elvégzett vizsgálat szerint a F. magna a Duna ártereitől nyugatra 80-110 km-es távolságokban is közönségesnek mondható a gímszarvas- és dám állományban is. A feltételezések szerint a métely új területeken történő megjelenését természetes és antropogén tényezők együttes hatása okozhatta a régióban. A Dráva folyóhoz közel eső területekre 
feltételezhetően a Duna irányából, a szarvasfélék migrációja következtében jutott el a métely, míg a Zselic területére vélhetőleg az ember közvetítésével, állatszállítással (Nagy és mtsai., 2018).

A természetes, a Dráva folyásirányával szemben történő terjedést támasztja alá egy horvát megfigyelés is. Ennek során, a négy évet felölelő időszak adatainak elemzése alapján bizonyítottá vált, hogy a féreg a Duna ártereinek irányából a Dráva felső folyását is elérte (Florijančić és mtsai., 2010). A szerzők megállapították, hogy a métely, különböző élőhelyek közti terjedésének elsődleges módja a fertőzött gímszarvasok mozgása és/vagy ember általi betelepítése, másodsorban pedig a fertőzött köztigazdák behurcolása.

Ez utóbbi jelenséget Németh (2018) kísérleti úton vizsgálva bizonyította, hogy a csülkös vadak szerepet játszhatnak a törpe iszapcsiga passzív úton történő terjedésében. A dagonyázó helyek iszapjával a állatok szőrébe tapadva juthatnak el egyik helyről egy másikra. Mivel a faj hímnős, egyetlen egyed is képes lehet populáció kialakítására a faj számára megfelelő élőhelyen. Bár a terjedés ilyen módja nem biztosítja a nagy távolságokra történő 'ugrást', ahhoz mindenféleképp elegendő lehet, hogy egy adott területen csigapopulációk alakulhassanak ki és/vagy a meglévő populációk egyedszáma növekedhessen.

A nagy amerikai májmétely új élőhelyekre történő terjedési képességét számos más kutatás is igazolta (VaderWaal és mtsai., 2015; Juhásová és mtsai., 2017; Escobar és mtsai., 2019). A megfigyelések és a predikciós modellek is azt a tényt támasztják alá, hogy a parazita inváziója nedves élőhelyeken (pl. ártéri területek, mocsarak, nedves rétek) várható elsősorban. Ezeken a területeken az időszakos vízborítottság és az ebből fakadó iszaplerakódás rendszeresen előforduló jelenség, amely optimális feltételeket biztosít azoknak a csigafajoknak, amelyek a féreg biológiai ciklusban szerepet játszanak.

Európában a F. magna köztigazdájaként három, a Lymnaeidae családba tartozó tüdős csigafaj játszhat szerepet. Jelen ismereteink szerint a Galba truncatula, a Radix peregra és a Radix labiata fajok képesek természetes úton fertőződni, illetve a csigákba bejutott miracídiumok cerkáriává fejlődni (ErhardováKotrlá, 1968; Faltýnková és mtsai., 2006; Leontovyč és mtsai., 2014). Több vizsgálat bebizonyította, hogy a három faj közül tömeges fertőződés csak a $G$. truncatula fajban fordul elő (Faltýnková és mtsai., 2006; Hörweg és mtsai., 2011; Leontovyč és mtsai., 2014).

A jelen vizsgálatban bemutatott élőhelyeken a $G$. truncatula és a Radix peregra is egyaránt előfordul (Fehér és Gubányi, 2001). Bár populációikra nézve pontos adatok nincsenek, feltételezhető, hogy a vizsgálati területeken talál- 
ható, lassú vízfolyások és kisebb tavak partjain számuk eléri azt a küszöbértéket, ami elősegítheti az amerikai májmétely megtelepedését és terjedését a régióban.

A vizsgálat adatai alapján feltételezhető a $F$. magna természetes, északi irányú terjedése a Dél-Dunántúlon. Az eddig Somogy megyében ismert legészakibb, előfordulás (46 8' 5,25" É; $17^{\circ} 29^{\prime}$ 4,22" K) és a vizsgált gímszarvasok elejtési helyszínei közti távolságok hasonlóak ahhoz, amit Horvátországban is tapasztaltak (Florijančić és mtsai., 2010) a parazita expanziója során. Véleményünket az egyes egyedekben tapasztalt intezitás-adatok is alátámasztják. Az alacsony féregszámok arra engednek következtetni, hogy a vizsgált egyedekben a métely új élőhelyeken történő megjelenése figyelhető meg (Hoberg és Brooks, 2015). Ezt támasztja alá az is, hogy az egyik állatban a 10 izolált féreg ellenére nem találtunk petét. Feltételezhető, hogy ezek a férgek nem érték el az ivarérettséget, ami a parazitában jellemzően a 120-150 napos prepatens periódus végén következik be.

Tovább erősíti hipotézisünket a gímszarvasra jellemző mozgáskörzet-adatok elemzése is. Általánosságban elmondható, hogy ennek nagysága szezonálisan változik, amelyet elsősorban az élőhely sajátosságai (pl. táplálék, búvóhely, pihenőhely, stb.) határoznak meg. Hazai vizsgálatok eredményei alapján elmondható, hogy a különböző élőhelyeken élő gímszarvas bikák mozgáskörzete 12-67 km², míg a teheneké és ünőké 0,4-64 km² között változik (Szemethy és mtsai., 1996; Szemethy és mtsai., 1998; Türke és mtsai., 2004; Náhlik és mtsai., 2009). Az anyai csapatot elhagyó, társakat, új otthonterületet kereső fiatal bikák elvándorlási tulajdonságai, csakúgy, mint a kifejlett bikák bőgési mozgásai nem ismertek. Ez utóbbival kapcsolatban azonban megemlíteni azt a vizsgálati eredményt, mely szerint a bikák akár több tíz kilométer távolságra is elvándorolhatnak (Náhlik és mtsai., 2009).

A fenti adatok alapján kiszámítható, hogy a faj mozgáskörzete egy 0,4- 4,6 km sugarú körre korlátozódik (Jarnemo, 2008). Ez a becsült távolság messze elmarad azoktól a távolságoktól, amelyeket a vizsgálat során számítottunk (21,0-37,8km). Így összegzésként valószínűsíthető, hogy a vizsgált gímszarvasok az elejtési hely közelében fertőződhettek.

\section{KÖVETKEZTETÉSEK}

Annak ellenére, hogy esetismertetésünkben a mintaszám kicsi, a rendelkezésre álló eredmények és a számított adatok alapján megállapítható, hogy a 2017-2018. évben Somogy és Baranya megyében megállapított $F$. magna endémia kiterjedése megnövekedett. Határozott északi irányú expanzió figyel- 
hető meg, amelyre alapozva, figyelembe véve az élőhelyi adottságokat és a gazdaszervezetek ismert dél-dunántúli sűrűségét, feltételezhető a további terjedés északi és nyugati irányba. Adataink alapján javasolt a monitoring-tevékenységet Zala megye déli, valamint Szlovénia Pannon-síksági területeire is kiterjeszteni.

Köszönetnyilvánítás: A szerzők ezúton fejezik ki hálás köszönetüket Laki Bencének, a Szent István Egyetem Kaposvári Campus munkatársának, valamint Herczeg Imrének a Nagybajom Környéke Gazdák Vadásztársaság vadászának a mintagyüjtésben nyújtott önzetlen segítségért.

\section{IRODALOMJEGYZÉK}

Campbell, W. C., Todd, A. C. (1954). Natural infections of Fascioloides magna in Wisconsin sheep. J. Parasitol. 40, 100-103.

Erhardová-Kotrlá, B., (1968). Parthenogenesis of Fascioloides magna (Bassi, 1875) under natural conditions. Folia. Parasitol. 15, 233-242.

Escobar, E. L., Moen, R., Craft, M. E., WanderWaal, K. L. (2019). Mapping parasite transmission risk from white-tailed deer to a declining moose population. Eur. J. Wild. Res. 65, 60. DOI: $10.1007 / s 10344-$ $\underline{019-1297-Z}$

Faltýnková, A., Horácková, E., Hirtová, L., Novobilský, A., Mordý, D., Scholz, T. (2006). Is Radix peregra a new intermediate host of Fascioloides magna (Trematoda) in Europe? Field and experimental evidence. Acta Parasitol., 51(2), 87-90. D0I: 10.2478/s11686-006-0013-9

Fehér, Z., Gubányi A. (2001). A magyarországi puhatestűek elterjedése - Az MTM Puhatestű-gyűjteményének katalógusa. Magyar Természettudományi Múzeum, Budapest.

Florijančić, T., Ozimec, S., Marinculić, A., Janicki, Z., Puškadija, Z., Bošković, I., Antunović, B. (2010). Importance of the Danube River in spreading the infection of red deer with Fascioloides magna in eastern Croatia. 38th IAD Conference, Dresden, Germany.

Foreyt, W. T., Todd, A. C. (1972). The occurrence of Fascioloides magna and Fasciola hepatica together in the livers of naturally infected cattle in South Texas, and the incidence of the flukes in cattle, white-tailed deer, and feral hogs. J. Parasitol. 58(5), 1010-1011. DOI: $10.2307 / 3286607$

Führer, E. (2018). A klímaértékelés erdészeti vonatkozásai. Erdészettud. Közl. 8(1), 27-42. DOI: $\underline{10.17164 / e k .2018 .002}$

Giczi, E. (2008). Hazai gímszarvas- és őzállományok Fascioloides magna (Bassi, 1875) fertőzöttsége és a védekezés lehetőségei. Doktori értekezés. Nyugat-Magyarországi Egyetem, Mosonmagyaróvár. pp 137.

Jarnemo, A. (2008). Seasonal migration of male red deer (Cervus elaphus) in southern Sweden and consequences for management. Eur. J. Wildl. Res. 54, 327-333. DOI: 10.1007/s10344-007-0154-7

Juhásová, L., Králová-Hromadová, I., Zeleňáková, M., Blišt’an, P., Bazsalovicsová, E. (2017). Transmission risk assessment of invasive fluke Fascioloides magna using GIS-modelling and multicriteria analysis methods. Helminthologia, 54(2), 119-131. DOI: 10.1515/helm-2017-0016

Hoberg, E. M., Brooks, D. R. (2015). Evolution in action: climate change, biodiversity dynamics and emerging infectious disease. Philos. Trans. R. Soc. Lond. B. Biol. Sci., 370(1665), 20130553. DOI: $\underline{10.1098 / r s t b .2013 .0553}$ 
Houszka, M., Piekarska, J., Podkowik, M., Gorczykowski, M., Bania J., (2016). Morphology and molecular study of Fascioloides magna - a growing threat to cervids (Cervidae) in Poland. J. Vet. Res., 60(4), 435-439. DOI: 10.1515 /jvetres-2016-0065

Hörweg, C., Prosl, H., Wille-Piazzai, W., Joachim, A., Sattmann, H. (2011). Prevalence of Fascioloides magna in Galba truncatula in the Danube backwater area east of Vienna, Austria. Wien. Tierärztl. Mschr. 98, 261-267.

Králová-Hromadová, I., Juhásová, L., Bazsalovicsová, E. (2016). The giant liver fluke, Fascioloides magna: past, present and future research. Springer International Publishing. eBook ISBN 978-3319-29508-4.

Leontovyč, R., Koštáková, M. Siegelová, V., Melounová, K., Pankrác, J., Vrbová, K., Horák, P., Kašný, M. (2014). Highland cattle and Radix labiata, the hosts of Fascioloides magna. BMC Vet. Res., 10(1), 41. DOI: $\underline{10.1186 / 1746-6148-10-41}$

Majoros, G. Sztojkov, V. (1994). Appearance of the large american liver fluke Fascioloides magna (Bassi, 1875) (Trematoda: Fasciolata) in Hungary. Parasit. Hung. 27, 27-38.

Marinculić, A., Džakula, N, Janicki, Z., Hardy, Z., Luèinger, S., Živiènjak, T. (2002). Appearance of american liver fluke (Fascioloides magna, Bassi, 1875) in Croatia-a case report. Vet. Arhiv. 72, 319-325.

Marinković D., Kukolj V., Aleksić-Kovačević S., Jovanović, M., Knežević M. (2013). The role of hepatic myofibroblasts in liver cirrhosis in fallow deer (Dama dama) naturally infected with giant liver fluke (Fascioloides magna). BMC Vet. Res., 9(1), 45. DOI: 10.1186/1746-6148-9-45

Nagy, E., Jócsák, I., Csivincsik, Á., Zsolnai, A., Halász, T., Nyúl, A., Plucsinszki, Zs., Simon, T., Szabó, Sz., Turbók, J., Nemes, Cs., Sugár, L., Nagy, G. (2018). Establishment of Fascioloides magna in a new region of Hungary: case report. Parasitol. Res. 117(11), 3683-3687. DOI: 10.1007/s00436-018-6099$\underline{9}$

Náhlik, A. Sándor, Gy., Tari, T., Király, G. (2009). Space use and activity patterns of red deer in a highly forested and in a patchy forest-agricultural habitat. Acta Silv. Lign. Hung., 5, 109-118.

Németh, V. (2018). A Galba truncatula csiga erdei nagyvadak segítségével történő terjedésének vizsgálata. Szakdolgozat. Állatorvostudományi Egyetem Parazitológiai és Állattani Tanszék. Budapest. pp 35.

Plötz, C., Rehbein, S., Bamler, H., Reindl, H., Pfister, K., Scheuerle, M. C. (2015). Fascioloides magnaepizootiology in a deer farm in Germany. Berl. Munch. Tierarztl. Wochenschr. 128, 177-182.

Rajský, D., Patus, A., Bukovjan, K. (1994). Prvýnález Fascioloides magna Bassi, 1875 na Slovensku. Slov. Vet. Čas. 19, 29-30.

Rehbein, S., Hamel, D., Reindl, H., Visser, M., Pfister, K. (2012). Fascioloides magna and Ashworthius sidemi - two new parasites in wild ungulates in Germany. In: Europ Multicoll Parasitol (EMOP) XI, Program and Abstracts. Cluj-Napoca, Romania. 565.

Ślusarski, W. (1955). Studia nad europejskimi przedstawicielami przywry Fasciola magna (Bassi, 1875), Stiles, 1894. I. Ponowne wykrycie ogniska inwazji u jeleni na Śląsku. Acta Parasitologica Polonica 3, 1-59.

Swales, W. E. (1935). The life cycle of Fascioloides magna (Bassi, 1875), the large liver fluke of ruminants in Canada: with observations on the bionomics of the larval stages and the intermediate hosts, pathology of Fascioloidiasis magna, and control measures. Can. J. Res., 12(2), 177-215. DOI: 10.1139/cjr35-015

Szemethy, L., Ritter, D., Heltai, M. Pető, Z. (1996). A gímszarvas tér-idő használatának összehasonlító vizsgálatai egy dombvidéki és egy alföldi élőhelyen. Vadbiológia, 5, 43-59.

Szemethy, L., Heltai, M., Mátrai, K., Pető, Z. (1998). Home ranges and habitat selection of red deer (Cervus elaphus) on a lowland area. Congress of the International Union of Game Biologists. Lyon. France. pp 7. 
Türke, I. J., Katona, K., Bleier, N., Szemethy, L. (2004). A gímszarvas napi mozgáskörzetének vizsgálata két különböző élőhelyen. Vadbiológia, 11.1-10.

Vaderwaal, K. L., Windels, S. K., Olson, B. T., Vannatta, J. T., Moen, R. (2015). Landscape influence on spatial patterns of meningeal worm and liver fluke infection in white-tailed deer. Parasitology, 142(5), 706-718. DOI: $10.1017 /$ s0031182014001802

Winkelmayer, R., Prosl, H. (2001). Riesenleberegel - jetzt auch bei uns? Österreichs. Weidwerk, 3, 4244.

(C) Copyright 2020 by the authors. This is an open access article under the terms and conditions of the Creative Commons attribution (CC-BY-NC-ND) license 4.0. 